\title{
COVID-19 Versus University Students Physical Activity
}

\author{
Ales Sekot ${ }^{1}$, Irena Durda ${ }^{2}$ \\ ${ }^{1}$ Department of Social Sciences and Management, Faculty of Sport Studies, Masaryk University, Brno, Czech Republic \\ ${ }^{2}$ Instituto Physical Education and Sport, Technical University of Ostrava, Ostrava, Czech Republic
}

Email address:

sekot@fsps.muni.cz (A. Sekot), irena.durdova@vsb.cz (I. Durda)

\section{To cite this article:}

Ales Sekot, Irena Durda. COVID-19 Versus University Students Physical Activity. International Journal of Sports Science and Physical Education. Vol. 6, No. 3, 2021, pp. 48-52. doi: 10.11648/j.ijsspe.20210603.12

Received: May 31, 2021; Accepted: June 10, 2021; Published: September 3, 2021

\begin{abstract}
PURPOSE: The aim of the paper is to present the results of a recent research survey (February 2021) in a broader context of the issue to determine whether university students devote themselves as much as possible to specific sports and physical activities even at the time of the ongoing pandemic associated with the spread of COVID-19. METHODS: To meet the objectives of the research survey, the method of questioning - an online questionnaire - was chosen. The total number of the university students who were addressed was 1164, 530 first-year students answered. The questionnaires were subjected to the statistical classification of the first-level data. RESULTS: The results of the research confirmed that first-year students of all VSB-TUO faculties, who as graduates of the relevant secondary school could no longer complete the subject Physical Education due to pandemic measures, preferred unorganized physical activities in accordance with the situation, such as walks, including walking the dog. $34.8 \%$ of respondents answered that they "did not miss sport" or that they "were not interested in sport at all". CONCLUSION: The study summarizes the latest reflections on impersonal forms of teaching of Physical Education on the motivation and intensity of sports and physical activities within the general level of foreign surveys as well.
\end{abstract}

Keywords: Physical Education, Sport, University Students, COVID-19

\section{Introduction}

The rapid and inexorable worldwide spread of the disease known as COVID-19 - presents, not only for Physical Education professionals, new and unforeseen challenges related to an unpredictable situation. Campus and all levels of school closures due to the pandemic created an urgent need to consider available alternatives to in-person programmes. Most notably, online Physical Education, which previously stood in the periphery of the field's vision [5] has been the subject of specific focus. Online Physical Education as the swift response to such situation the period of closing of schools and the months of social distancing have shifted the site of learning to the home: Physical Education (PE) and organized active recess time that would typically occur in school have been either cancelled or made a part of digital home-schooling as distance education and online learning [7], The present pandemic in such perspective has merely punctuated the need to explore integrating such innovations into 21 st-century teaching and learning (respecting inadequate physical spaces for participation [2]. Notably, a body of evidence already exists to suggest that, when supported with appropriate pedagogical practices, digital technologies, such as social media, blogs, video analysis, and video games can be effectively integrated into Physical Education to enhance students' learning [1]. In such context we can speak about new challenges of pandemic situation, (e.g., teacher feedback and responsiveness, understanding and interest related to the content, and perceived health gains) compared to students enrolled in in-person programmes [18].

All current developments in society have been marked and subjected to the fight against the spread of the Covid-19 viral disease in our public space for many months. The effort of society and the imperative of each individual's behaviour and actions is to protect themselves, their families and the people around them from COVID-19, while maintaining the usual quality of life. The ongoing COVID-19 pandemic is currently a global societal crisis affecting all areas of human activity, including sport. 
Temporary practical experience with COVID-19 also enhanced and enriched our visible and tangible impacts regarding limitations or even restrictions of sportive activities in the context of contemporary sedentary society: The need to stay mainly in the home environment has led to reduction in physical activity and exacerbation of the negative attributes of the passive way of of life of consumerist society. The result is sedentary, physically inactive passive style in most professions, in the environment of households and individual forms of transport [14]. Cancellation or extreme restrictions of the school subject Physical Education, organization of sports clubs, and closed sports grounds make it impossible in a completely unprecedented way to conduct sports leisure activities, which has a negative effect on the physical fitness of children, youth and adults, and, in the medium or long term, also on their wellbeing, and, therefore, the state of health. At the same time, physical activity is one of the strongest weapons in the fight against diseases of civilization, it serves to strengthen physical and mental health [5].

\section{The Importance of Sports Activities}

Experts, medical doctors and educators had pointed out the crucial importance of regular physical exercise and the consequences of physical inactivity long before the outbreak of the COVID-19 pandemic [5]. With increasing urgency, it is emphasized that regular physical activities as an integral part of lifelong individual "rituals" are a prerequisite for the individual's overall development on the path to physical and mental health. E.g., exercise performed with a medium intensity of 20-30 minutes 3-4 times a week significantly strengthens the immune system and thus reduces the risk of possible viral infection. [9]. At the same time, it is recalled that, on the other hand, a single high-intensity exercise in untrained individuals can lead to impaired immunity and an increased risk of infection. [16]

During the COVID-19 pandemic, are urgently actualized WHO currently recommends for moderate-intensity physical activity for at least 140 minutes a week [17]. Adequate physical activity is a prevention of many diseases, supports the proper function of the immune system, and contributes to better coping with stressful situations. Exercise is an integral part of mental hygiene, and stress management appears to be essential in demanding quarantine conditions and implementing all pandemic measures all pandemic measures [19]. Specific recommendations of sport science relating to given populations are recommended [10].

In their article dealing with physical activity during the COVID-19 pandemic, the authors Pudilová and Tuka from the Czech Society of Sports Medicine emphasize several rules for physical activity of the population that would not contradict government measures and are, at the same time, safe for those who perform physical exercises [11]:

1) Avoid very high-intensity physical activities.
2) Do not exercise if you have symptoms of incipient viral infection.

3) After the viral infection has subsided, start physical activity slowly.

4) Adjust the intensity and strenuousness of physical activity to your personal level of training.

5) It is necessary to consider the previous restrictions resulting from your internal diseases or diseases of the musculoskeletal system.

6) If any pain occurs during a particular physical activity, do not try to overcome it.

7) Do not forget a regular drinking regime, a healthy diet, and enough sleep.

8) Even when releasing the quarantine, it is better to avoid indoor sports grounds and places with a higher concentration of people, especially if you are being treated for a chronic disease or you belong to the risk groups.

9) Be in a positive mood. Remember that keeping yourself merry and cheerful is key for staying healthy.

The idea that physical activity has a positive effect on physiological functions was developed at the end of the last decade to claim that physical activity can positively affect the symptoms of stress due to health threats and, last but not least, contribute to reducing stress related to isolation and limiting social contacts [10]. The role of Physical Education lessons for pupils and students are accented is accented as an indispensable part of school curriculum [8].

\section{COVID-19 Versus Physical Activity}

Global spreading of the COVID-19 has been striking and uncompromisingly against natural way of live of society and as well most social groups and individuals: Negative impacts on social and physical distancing measures, lockdowns of businesses, schools and overall social life, have also disrupted many regular aspects of life, including sport and physical activity: the closure of gyms, stadiums, pools, dance and fitness studios, physiotherapy centres, parks, and playgrounds on the last analyse means that many individuals are not able to actively participate in their regular individual or group sporting or physical activities outside of their homes Consequently lack of access to regular sporting or exercise routines may result in challenges to the immune system, physical health, and it may lead to the commencement of or exacerbating existing diseases that have their roots in a sedentary lifestyle [12].

For many, exercising at home without any equipment and limited space is problematic if not impossible. For those whose home life (and even more home-office) involve long periods of sitting, for example walking, biking, running, stretching, doing housework, climbing stairs or dancing to music is natural source of absenting physical activity. In addition internet and video physical fitness games, for example, can be appealing to people of all ages and can be used in small spaces. 


\section{Opinions of University Students on the Changing Conditions of Physical Education}

Physical Education at schools is thus limited or completely suspended during the fight against the pandemic. Due to the nature of this subject, remote approach is almost impossible; in addition, preference in teaching was given to theoretical subjects. The term school Physical Education refers to children, youth and adults from primary and secondary schools to universities. Gradually, Physical Education teachers began to engage in contact with pupils and students using mobile applications or online teaching. Without previous experience, they started shooting training videos, encouraging regular sports activities, and emphasizing the importance of indoor activities.

Teachers at the Institute of Physical Education and Sports were also fully aware of the risks involved in banning fulltime Physical Education. The impossibility of contacts with students led to the severance of relations between the IPES (teaching, winter and summer sports courses) and students of all grades. The consequences of the cancelled university PE at VSB-TUO for first-year students of all faculties are particularly noticeable, not only in terms of the offer of physical exercises but also in the equally significant level of limiting social contacts. Students of the first years of universities in the academic year 2020/2021 are also those who completed their secondary school studies at the pandemic and were affected by epidemiological measures in the final year of secondary school. After about 14 days of full-time teaching at the university, they were again dependent on the distance form of education. They did not have enough time to get acquainted with the course of study at the university, they did not gain contacts with students in higher years, and probably they do not even know the other members of the created study groups.

IPES at VSB-TUO has long been interested in the opinions of VSB-TUO students on teaching PE, and their leisure-time physical activities. Whenever it has been possible, IPES has always adapted the offer of physical exercises to the requirements of the respondents - VSB-TUO students. Research surveys with the aim of finding out students' opinions on teaching PE and its quality, on the possibilities of sports at VSB-TUO, on the level of the sports environment, has been conducted repeatedly since 1998, the number of respondents ranged up to 500 respondents. The survey took the form of filling in questionnaires in paper form, since 2015, using modern electronic technologies. The last research before the COVID-19 pandemic took place in 2018 [4]; 530 respondents, students of all years and all faculties of VSB-TUO took part in the online survey out of 2469 students who had been addressed. We were interested in the choice of sport, in satisfaction with sports activities at VSB-TUO, in preferring a specific day and time to exercise during the day. We were also interested in how many times a week students use the DPES' offer for their leisure activities. This research survey showed a positive evaluation of the work of the DPES
(23\% of respondents were very satisfied with the programme offered, and $47.5 \%$ stated that they were rather satisfied, while only $5.8 \%$ were rather dissatisfied and $1.5 \%$ were very dissatisfied). Similarly, students evaluated the possibilities of $\mathrm{PE}$ and sport at VSB-TUO $-28.3 \%$ were very satisfied, and a total of $49.4 \%$ of respondents were satisfied. We also obtained very similar results as in the questionnaire survey from 2018 by the survey in 2015 [13].

The IPES has always been very focused on building a relationship with students interested in sports. Most often, contacts took place during TV lessons, sports courses or during trainings of the university sports club (USC at VSBTUO). The IPES has regularly organized a number of sports events for students (or employees). It had a daily offer of physical activities in the afternoon and evening at the VSBTUO sports grounds. The IPES has come up with a wide range of physical exercises during each exam period. The IPES has regularly organized traditional university-wide large sports events with the support of the Rector of the university - e.g. VSB-TUO Sports Day, VSB-TUO Technika Run running race, a weekly suburban sports camp for children of VSB-TUO employees, once a week exercises for school kindergarten children.

The last targeted survey of VSB-TUO students under the auspices of IPES took place in February 2021, at the time of the $\mathrm{PE}$ ban and the consequences of measures related to limiting the spread of COVID-19. In this survey, we were mainly interested in the first-year students. As previously mentioned, these students did not have continuous teaching of PE in the second half of the last year at the secondary school $(2019 / 2020)$ or in the winter semester of the academic year 2020/2021.

The online questionnaire survey in February 2021 was attended by 1164 respondents, the 1st year students of all seven faculties of VSB-TUO. There were 758 men and 406 women, $32.2 \%$ of whom were students of the Faculty of Economics and $22.8 \%$ of the Faculty of Electrical Engineering and Computer Science. The other five faculties did not differ much in the number of respondents, and it was $10-16 \%$ of the total number of respondents.

When asked whether students currently, at the time of epidemiological measures, miss sports activities, $65.2 \%$ answered "yes, I do", 25.3\% "No, I do not", and 9.5\% answered that they were "not interested in sport".

Another question concerned physical activities that respondents could perform themselves during epidemiological measures. The answers can be summarized as follows:

1) I did exercise at home (42.5\%),

2) I took the opportunity to play sports in nature $(31.4 \%)$,

3 ) I did not regularly engage in physical activities (22.3\%),

4) I did not perform any physical activities (3.8\%).

By asking about specific regularly performed sports activities, the following order of activities was created:

1) walks, including walking the dog,

2) regular exercise at home,

3) running,

4) cycling, 
5) Nordic walking,

6) other physical activity.

Other questions was interested in the involvement of students in activities offered by the IPES VSB-TUO at the time of the release of epidemiological measures (outdoor sports ground, gym, aerobic hall - always in compliance with the permitted number of people and all epidemiological measures). $74.1 \%$ "did not use this option at all". This fact is certainly influenced by the fact that students accommodated at VSB-TUO university dormitories moved out and went to their places of permanent residence. $15.4 \%$ of respondents used the opportunity to play sports at VSB-TUO sports grounds (albeit with restrictions) "very often" and 10.6\% of respondents "occasionally".

When, due to the worsening pandemic situation in the Czech Republic, all sports activities were banned, the IPES offered short video training (aerobic exercises, stretching, Pilates, circle training) on its Youtube channel, which could be used for doing exercise at home.

When asked whether these videos were a stimulus or inspiration for doing exercise at home, the vast majority of respondents $(73 \%)$ answered that they did not know about these videos at all. At the same time, notifications about the possibility of training online under the guidance of the IPES teachers were announced on the IPES website or the IPES Facebook.

The answer of the respondents to a specific question also leads to reflection: "Do you miss organized Physical Education at VSB-TUO?". Their answers:

1) I miss it very much $(24.4 \%)$,

2) Thanks to teaching PE, I had the opportunity to play sports at least once a week (31.3\%),

3) I do not miss it at all (44.3\%).

It should be reminded again that the respondents - the firstyear students, due to government measures and the introduction of distance learning, practically did not have time to look around the university, did not get acquainted with the university environment and university specifics. They did not find opportunities for sports at VSB-TUO and did not get acquainted with the offer of sports activities of IPES. Since mid-September 2020 , when the distance form of teaching was introduced, it has been impossible to play sports and use the well-equipped VSBTUO sports grounds. We firmly believe that we will once again continue the regular teaching of PE, the traditional offer of the IPES sports activities in the academic year 2021/2022. Unfortunately, we have lost the students of the first years of the academic year 2020/21 and let us hope that the IPES will have to strive for them with a well-established offer of sports activities in the nearest possible future.

\section{Conclusion}

Across the world, millions of students have experienced the disruption of their normal routines for learning and physical activity [12]. It is demonstrable fact that regular sports and physical exercise not only affect physical and mental health but that they strongly affect the immune system of those who do physical activities is accepted, then a one-year break from PE in the case of children and adolescents can have serious, as well as far-reaching consequences. If the relationship to sports is not supported in the family [15], the absence of PE, closed playgrounds, and sports grounds can negatively affect the health of children, youth, and the general population. In this context, the sociopsychological and highly socializing significance of Physical Education, physical exercises and games cannot be underestimated. Joy, relaxation, healthy competition in the company of friends during physical activities leads to positive feelings and moods to stress reduction.

If sport is not part of the family or individual lifestyle, it will be the duty of Physical Education teachers, sports coaches, and all sports activists to try to return children, young people, the general public, and sports grounds and encourage regular diverse sports activities.

Furthermore, last but not least, search if such an unprecedented situation could reveal new ways, horizons, or methods to motivate children and young people to regular sportive activities and adherence to the sport as an integral part of lifestyle(s). We face the task to dare to make vital step to search for and find a solution to how parents, peers, coaches, and sports organizations can effectively engage with each other during the crisis and during return to play.

In growing urgency, the educational institutions have to take into account that also for parents, it is recommendable to be a positive role model [15]. And in the specific situation of distance learning and perhaps training, guidance from their teachers, coaches and parents in a unique and unrepeatable situation can help the children find productive, favourable, meaningful ways to spend that time, rather than spending hours and hours in front of a screen. Supporting children to stay busy helps them to avoid focusing all of their attention on the negative ramifications of the pandemic, such as event cancellations, school closures, and social isolation. Not being able to compete could be a potential identity crisis for some athletes. Therefore, it is a priority to let children and young people enjoy feelings of intensive physical sportive experiencing. School and parental investment can help ease the pain and confusion they might be feeling, helping children find ways to be productive, physically and mentally active, and take care of themselves physically and mentally in a pandemic situation.

\section{References}

[1] Bodsworth, H., \& Goodyear, V. A. (2017). Barriers and facilitators to using digital technologies in the Cooperative Learning model in Physical Education. Physical Education and Sport Pedagogy, 22 (6), 563-579. doi: 10.1080/17408989.2017.1294672.

[2] Collin A. Webster, E., D’Agostino,, M., Urtel, J., \& Chad Killian, Ch. (2020). Physical Education in the COVID Era: Considerations for Online Program Delivery Using the Comprehensive School Physical Activity Program Framework. Journal of Teaching in Physical Education.. https:/journal of humankinetics.com 
[3] Daum, D. N., \& Buschner, C. (2014). Research on teaching blended and online Physical Education. In R. E. Ferdig\& K. Kennedy (Eds.), Handbook of Research on $\mathrm{K}-12$ Online and Blended Learning (1st ed., pp. 201-222). Pittsburg, PA: ETC Press.

[4] Durdová, I (2019). Tělesná výchova a sport vysokoškolské mládeže. In: Vysokoškolská telesná výchova a šport, pohybová aktivita a zdravý životný štýl (recenzovaný sborník vědeckých prací). Košice: Technická univerzita v Košicích, s. $39-45$.

[5] Ferdig \& K. Kennedy (Eds.) (2017) Handbook of Research on K-12 Online and Blended Learning (1st ed., pp. 201-222). Pittsburg, PA: ETC Press.).

[6] Kooiman, B. J. (2017). Moving online Physical Education from oxymoron to efficacy. Sport, Education and Society, 22 (2), 230-246.

[7] McElroy, M. (2002). A Social Analysis of Inactivity. Champaign: Human Kinetics.

[8] Mužík, V. \& Krejčí, (1997). Tělesná výchova a zdraví. Olomouc: Hanex.

[9] Nieman, D. C., Nehlsen-Cannarella, S. L., Markoff, P, A, et al. (1990) The effects of moderate exercise training on natural killer cells and acute upper respiratory tract infections. In $J$ Sports Med 11: 467-473. In R. E.

[10] Powell, K. E., King, A. C., Buchner, D. M., Campbell, W. W., DiPietro, L., Erickson, K. I., Hillman, C. H., Jakicic, J. M., Janz, K. F., Katzmarzyk, P. T., \& Kraus, W. E., (2018). The scientific foundation for the physical activity guidelines for Americans. Journal of Physical Activity and Health, 16 (1), pp. 1-11.
[11] Pudilová, V; Tuka, V: (2021). Pohybová aktivita $v$ době pandemie COVID-19. Dostupné na: https://www.kardiocz.cz/2020-03-28-pohybova-aktivita-v-dobe-pandemie-covid$19 /$

[12] Roe, A., Pedersen, C., Dalland, S at al. (2021) The Impact of COVID and Homeschooling on Students' Engagement With Physical Activity. Front. Sports Act. Living, 26 January 2021 https://doi.org/10.3389/fspor.2020.589227

[13] Sekot, A; Irena Durdová, I; Pětivlas, T; Krčmářová, J. (2016). Pohybové aktivity studentů VSB-TU Ostrava v kontextu sedavé společnosti. Studia Sportiva., roč. 10, č. 1, s. 8-14.

[14] Sekot, A. (2015). Pohybové aktivity pohledem sociologie. Brno: Masarykova univerzita.

[15] Sekot, A. (2019). Rodiče a sport dětí. Brno: Masarykova univerzita.

[16] Simpson, RJ, Campbell, JP, Gleeson, M, et al. (2020). Can exercise affect immune function to increase susceptibility to infection? Exerc Immunol Rev 26: 8-22.

[17] WHO. (2021) Lack of exercise kills. How long should we exercise daily? - CNN Prima NEWS? - CNN Prima NEWS (iprima.cz).

[18] Williams, L., Martinasek, M., Karone, K., \& Sanders, S. (2020). High school students' perceptions of traditional and online health and Physical Education courses. Journal of School Health, 90 (3), 234-244. doi: 10.1111/josh.12865.

[19] Wrihht, K, \& McDonald, D. (2010). Young People, Physical Activity and the Everyday. Routledge: London and New York. 